\title{
Bacterial Vaginosis as a Risk Factor for Preterm Labour-An Analysis of Age and Duration of Marriage
}

\author{
Zaheera Saadia ${ }^{1,}$, Robina Farrukh², Sadia Asghar² \\ ${ }^{1}$ Department of Obstetrics and Gynecology Qassim University, Al-Qassim, Kingdom of Saudi Arabia \\ ${ }^{2}$ Department of Obstetrics and Gynecology Sir Ganga Ram Hospital, Lahore, Pakistan
}

Email address:

zaheerasaadia@hotmail.com (Z. Saadia),robinafarukh@gmail.com (R. Farrukh), azanayan36@gmail.com (S. Asghar)

*Corresponding author

\section{To cite this article:}

Zaheera Saadia, Robina Farrukh, Sadia Asghar. Bacterial Vaginosis as a Risk Factor for Preterm Labour-An Analysis of Age and Duration of Marriage. Journal of Gynecology and Obstetrics. Vol. 4, No. 6, 2016, pp. 68-71. doi: 10.11648/j.jgo.20160406.17

Received: December 5, 2016; Accepted: December 16, 2016; Published: January 12, 2017

\begin{abstract}
Preterm labour is the onset of labour between $\geq 24$ weeks to $<37$ weeks of gestation. Bacterial Vaginosis (BV) is a polymicrobial condition with predominant lactobacilli in the vaginal flora. It is an important risk factor for preterm labour with an incidence of $5-18 \%$ of all deliveries causing increased perinatal morbidity and mortality with subsequent neurodevelopmental problems as cerebral palsy. We aimed to determine the association of BV with preterm labour population. A case control study was conducted comparing the prevalence of bacterial vaginosis in women having term labour with those who had preterm delivery. Chi square test was used to compare differences in participants' age, duration of pregnancy and duration of marriage. Odd ratio and CI was calculated for the association between BV and preterm labour. Nearly half of the participants that experienced preterm labour were between 21 and 25 years old $(46.7 \%, n=35)$ and nearly half of the participants that experienced term pregnancy were between 21 and 25 years old as well $(48.0 \%, n=36)$. Additionally, the majority of participants had been married for three to four years, for those that experienced preterm labour $(64.0 \%, n=48)$ and term pregnancy $(52.0 \%, n=39)$. Furthermore, nearly half of the participants' duration of pregnancy was between 33 and 34 weeks $(49.3 \%, n=37)$ and $52.0 \%$ of participants who experienced term pregnancy had been pregnant for 37 to 38 weeks $(n=$ 39). Women with Bacterial Vaginosis, experienced preterm labour in $26.7 \%$ cases $(n=20)$ as compared to those who had term pregnancy $12.0 \%(n=9)$. BV was significantly associated with preterm labour $(\mathrm{OR}=7.3,95 \% \mathrm{CI}=1.9-27.5, \mathrm{P}=0.003)$. There was no significant difference in participants' age between preterm labour and term pregnancy groups, $(\mathrm{p}$ value $=0.880$ ). Additionally, there was no significant difference in participants' duration of marriage between preterm labour and term pregnancy groups, ( $\mathrm{p}$ value $=0.801)$. Bacterial Vaginosis is a risk factor for preterm labor. The study also concluded that there is no significant association between age, duration of pregnancy and duration of marriage between preterm labour and term pregnancy groups.
\end{abstract}

Keywords: Pregnancy, Bacterial Vaginosis (BV), Preterm Labour

\section{Introduction}

Preterm labour is the onset of labour between $\geq 24$ weeks to $<37$ weeks of gestation. It is determined by uterine contractions with frequency of four per 20 minutes or eight per 60 minutes, accompanied by one of the following: Preterm rupture of membranes (PROM), cervical dilation greater than $2 \mathrm{~cm}$, effacement exceeding 50 percent, or a change in cervical dilation or effacement detected by serial examinations [1]. $\mathrm{BV}$ is a polymicrobial infection characterized by replacement of normal vaginal flora which is rich in lactobacilli, with anaerobes. It is confirmed by Amsel's criteria which includes presence of thin homogenous vaginal discharge, $\mathrm{pH}$ above 4.5 , positive Whiff's test and presence of clue cells on microscopy. Three out of above four signs is required to make a diagnosis [2] .

Preterm birth and its consequences remain a major health problem. The incidence is reported to be $5-18 \%$ of all deliveries, causing increased perinatal morbidity and mortality [3]. The etiology of preterm birth is multifactorial but now there is well accepted evidence to implicate 
infection as a cause [4]. Prevalence of BV has been estimated to be $28.1 \%$ and is considered as an important risk factor for preterm labour [5]. The cost of neonatal intensive care in short term, and the resources needed to support children with long term morbidity as a result of preterm birth are considerable. Preventable and treatable causes of preterm labour should be identified and dealt with for the better maternal and fetal outcome [5]. BV produces enzymes and immune stimulators (cytokines) in the vagina and uterus that promote cervical ripening and weakening of fetal membranes, as well as prostaglandin production that increase the uterine contractions [6]. BV in pregnancy has been linked with poor perinatal outcome including preterm labour and preterm birth. Identification and treatment may reduce the risk of preterm birth and its consequences [7]. We aimed to determine the association of $\mathrm{BV}$ with preterm labour in our study population, as well as tried to find out the association with age of the patient, duration of marriage and duration of pregnancy. Because of the adverse fetal consequences of the condition, it's important that we continue to look for new risk factors.

\section{Subjects and Methods}

A case control study was conducted at the Department of Obstetrics and Gynecology Sir Ganga Ram Hospital, Lahore for a period of six months from Jan - June 2015. Sample size of 150 patients' 75 cases and 75 controls was calculated with power of 80 and $10 \%$ margin of error taking expected percentage of bacterial Vaginosis $(9-23 \%$ of pregnant women) [8]. Women included in the study were those with gestation age $\geq 24$ weeks to $<37$ weeks by dating scan with preterm labour (as per operational definition given in the introduction). Controls were the women with gestational age $\geq 37$ weeks by dating scan. Women with age between 18-35 years and singleton pregnancy were included in the study for both cases and controls. Women with history of previous miscarriage, previous preterm deliveries, ruptured membranes smoking, fetal malformations on ultrasound, polyhydramnios, any medical disorder and women with consumption of antibiotics within 3 months were excluded from the study, because they are well established risk factors for $\mathrm{BV}$, and their exclusion avoided the effect of these confounders.

Vaginal discharge was observed by performing speculum examination and $\mathrm{pH}$ was measured by $\mathrm{pH}$ strips. Whiff test was performed by placing few drops of $10 \% \mathrm{KOH}$ on a glass slide mixed with discharge; a rotten fish odour renders the test positive. A saline wet smear was made for direct microscopy and presences of clue cells were noted. If three or more findings were present the diagnosis of BV was confirmed. Informed consent was taken from the patients and data was kept anonymous for privacy. The study was approved by the Institutional Review board of the hospital.

The data was entered in SPSS 23. Chi square test was used to compare differences in participants' age, duration of pregnancy and duration of marriage. Odd ratio and CI was calculated for the association between $\mathrm{BV}$ and preterm labour.

\section{Results}

Nearly half of the participants that experienced preterm labour were between 21 and 25 years old $(46.7 \%, n=35)$ and nearly half of the participants that experienced term pregnancy were between 21 and 25 years old as well (48.0\%, $n=36$ ). Additionally, the majority of participants had been married for three to four years, for those that experienced preterm labour $(64.0 \%, n=48)$ and term pregnancy $(52.0 \%$, $n=39)$. Furthermore, nearly half of the participants' duration of pregnancy was between 33 and 34 weeks $(49.3 \%, n=37)$ and $52.0 \%$ of participants who experienced term pregnancy had been pregnant for 37 to 38 weeks $(n=39)$. Displayed in Table -1 is a cross tabulation of participants' age, duration of marriage, and duration of pregnancy by preterm labour and term pregnancy groups.

Table 1. Cross Tabulation of Participants'Age, Duration of Marriage, and Duration of Pregnancy by Preterm Labour and Term Pregnancy Groups.

\begin{tabular}{|c|c|c|c|c|}
\hline \multirow[b]{2}{*}{ Variable } & \multicolumn{2}{|c|}{ Preterm Labour Group } & \multicolumn{2}{|c|}{ Term Pregnancy Group } \\
\hline & Frequency $(n)$ & Percent (\%) & Frequency $(n)$ & Percent (\%) \\
\hline \multicolumn{5}{|l|}{ Age } \\
\hline $18-20$ years & 6 & 8.0 & 8 & 10.7 \\
\hline $21-25$ years & 35 & 46.7 & 36 & 48.0 \\
\hline $26-30$ years & 26 & 34.7 & 21 & 28.0 \\
\hline $31-35$ years & 8 & 10.7 & 10 & 13.3 \\
\hline Total & 75 & 100.0 & 75 & 100.0 \\
\hline \multicolumn{5}{|c|}{ Duration of marriage } \\
\hline $1-2$ years & 27 & 36.0 & 32 & 42.7 \\
\hline 3 - 4 years & 48 & 64.0 & 39 & 52.0 \\
\hline $5-6$ years & 0 & 0.0 & 4 & 5.3 \\
\hline Total & 75 & 100.0 & 75 & 100.0 \\
\hline \multicolumn{5}{|c|}{ Duration of pregnancy } \\
\hline 31 - 32 weeks & 20 & 26.7 & 0 & 0.0 \\
\hline 33 - 34 weeks & 37 & 49.3 & 0 & 0.0 \\
\hline 35 - 36 weeks & 18 & 24.0 & 0 & 0.0 \\
\hline 37 - 38 weeks & 0 & 0.0 & 39 & 52.0 \\
\hline 39 - 40 weeks & 0 & 0.0 & 36 & 48.0 \\
\hline Total & 75 & 100.0 & 75 & 100.0 \\
\hline
\end{tabular}


The majority of participants that experienced preterm labour did not have Bacterial Vaginosis $(73.3 \%, n=55)$ as well as those who experienced a term pregnancy $(88.0 \%, n=66)$. For those that did have Bacterial Vaginosis, 26.7\% experienced preterm labour $(n=20)$ and $12.0 \%$ experienced term pregnancy $(n=9)$. Displayed in Table -2 is a cross tabulation of preterm labour and term pregnancy groups by Bacterial Vaginosis status.

Table 2. Cross Tabulation of Participants' Bacterial Vaginosis Status by Preterm Labour and Term Pregnancy Groups.

\begin{tabular}{|c|c|c|c|c|c|c|}
\hline \multirow[b]{2}{*}{ Bacterial Vaginosis } & \multicolumn{2}{|c|}{ Preterm Labour Group } & \multicolumn{2}{|c|}{ Term Pregnancy Group } & \multicolumn{2}{|c|}{ Chi square and P-value } \\
\hline & Frequency $(n)$ & Percent (\%) & Frequency $(n)$ & Percent (\%) & & \\
\hline Yes & 20 & 26.7 & 9 & 12.0 & & \\
\hline No & 55 & 73.3 & 66 & 88.0 & $\chi^{2}$ & 5.17 \\
\hline Total & 75 & 100.0 & 75 & 100.0 & P-value & 0.019 \\
\hline
\end{tabular}

Results of Research Question 1

Null Hypothesis $1\left(\mathrm{H}_{\mathrm{O}} 1\right)$ : Bacterial Vaginosis is not a risk factor for preterm labour.

Alternative Hypothesis $1\left(\mathrm{H}_{\mathrm{A}} 1\right)$ : Bacterial Vaginosis is a risk factor for preterm labour.

Using SPSS 23.0, risk analysis was conducted to determine if bacterial vaginosis was a risk factor for preterm labour. In binary regression BV was significantly associated with preterm labour $(\mathrm{OR}=7.3,95 \% \mathrm{CI}=1.9-27.5, \mathrm{P}=0.003)$

Results of Research Question 2

Null Hypothesis $2\left(\mathrm{H}_{\mathrm{O}} 2\right)$ : There is no significant difference between age, duration of pregnancy and duration of marriage between preterm labour and term pregnancy groups.
Alternative Hypothesis $2\left(\mathrm{H}_{\mathrm{A}} 2\right)$ : There is a significant difference between age, duration of pregnancy and duration of marriage between preterm labour and term pregnancy groups.

Using SPSS 23.0, chi-squared test of independence was conducted to determine if there were significant differences in participants' age, duration of pregnancy and duration of marriage existed between preterm labour and term pregnancy groups. Displayed in Table -3 is a cross tabulation of participants' age and duration of marriage by preterm labour and term pregnancy groups used for the chi-squared analyses of research question 2 .

Table 3. Comparing the mean (SD) of the age, duration of marriage and gestational age between cases and controls. Analyses of Research Question 2.

\begin{tabular}{lllll}
\hline & Preterm Labour Group & Term Pregnancies Group & $\chi^{2}$ value & P-value \\
\hline Variable & $\mathbf{N}=\mathbf{7 5}$ & $\mathbf{N}=\mathbf{7 5}$ & & \\
\hline Age in years & $25.1(3.6)$ & $25.0(3.9)$ & 1.054 & 0.880 \\
Duration of marriage & $3.2(4.9)$ & $3.1(3.3)$ & 5.355 & 0.069 \\
Gestational age in weeks & $33.4(1.5)$ & $38.2(3.2)$ & 1.465 & $<0.001$ \\
\hline
\end{tabular}

Results from the chi-squared analysis indicated there was no significant difference in participants' age between preterm labour and term pregnancy groups, ( $p$ value $=0.880$ ). Additionally, results from the chi-squared analysis indicated there was no significant difference in participants' duration of marriage between preterm labour and term pregnancy groups, ( $\mathrm{p}$ value=0.069) Thus, the null hypothesis for research question 2 was retained. The only observed significant difference was gestational age ( $\mathrm{p}$ value $=<0.001)$.

\section{Discussion}

Bacterial Vaginosis is a common condition. It is a polymicrobial disorder with an overgrowth of facultative bacteria and a reduction or total absence of the colonization of lactobacillus [9]. Several adverse outcomes are associated with Bacterial Vaginosis including upper genital tract infection leading to pelvic inflammatory disease and preterm birth [10]. Preterm birth has indeed been associated with adverse perinatal outcome with all the known complications of prematurity including respiratory distress and cerebral palsy (11). Previous miscarriage, periodontal disease, malnutrition and low BMI (below 25) and short inter pregnancy interval are the risk factors for preterm birth [12]. Bacterial vaginosis is an established risk factor for preterm labour $(7,8)$ which is consistent with the results of our study, as we observed higher prevalence of Bacterial vaginosis in preterm deliveries. In fact the risk is twofold with critical period during an early gestation as reported by Verstraelen et al [13].

Also of importance to note from the study is that, there is not a significant difference between age, duration of pregnancy and duration of marriage between preterm labour and term pregnancy groups. Thus a person's age does not determine their likelihood to Bacterial vaginosis and thus preterm labor. Also, a person's duration of marriage does not affect their preterm labor or term pregnancy. As the prevalence of preterm births is increasing there is a need to find out all possible risk factors so that timely measures can be taken to prevent women delivering a preterm baby. Pregnancy itself is known to alter the vaginal flora and predisposes to $\mathrm{BV}$ which many at times goes undetected because many women are asymptomatic [14]. Our study reports a strong association of $\mathrm{BV}$ with preterm birth and the condition is very easy to treat by antibiotics, hospital protocols should screen all pregnant women early in pregnancy to prevent preterm birth. Our study has the limitation of small sample size. Study has the strength of being a case controlled study. Being conducted in a tertiary care hospital situated in the center of the city, we assume that our study population is representative of the community. We recommend further studies to assess the risk factors for $\mathrm{BV}$ 
as well as look for other novel markers for assessing the risk of preterm labour.

\section{Conclusion}

$\mathrm{BV}$ is a strong risk factor for preterm labour and delivery. This being a preventable and treatable cause should be identified and dealt with for the better feto maternal outcome. As BV appears quite prevalent in our study population and increases the risk of preterm delivery. We should continue to look for new risk factors, so that appropriate strategies should be planned, if a new association is discovered.

\section{References}

[1] Von Der Pool BA. Preterm labor: diagnosis and treatment. Am Fam Physician. 1998 May 15; 57 (10): 2457-64. Review.

[2] Islam A, Safdar A, Malik A. Bacterial vaginosis. J Pak Med Assoc. 2009 Sep; 59 (9): 601-4.

[3] Georgiou HM, Di Quinzio MK, Permezel M, Brennecke SP. Predicting Preterm Labour: Current Status and Future Prospects. Dis Markers. 2015; 2015: 435014. doi: 10.1155/2015/435014. Epub 2015 Jun 15. Review. PubMed PMID: 26160993; PubMed Central PMCID: PMC4486247.

[4] Waring GJ, Robson SC, Bulmer JN, Tyson-Capper AJ. Inflammatory Signalling in Fetal Membranes: Increased Expression Levels of TLR 1 in the Presence of Preterm Histological Chorioamnionitis. PLoS One. 2015 May 12; 10 (5): e0124298. doi: 10.1371/journal.pone.0124298. eCollection 2015.

[5] Krauss-Silva L, Almada-Horta A, Alves MB, Camacho KG, Moreira ME, Braga A. Basic vaginal $\mathrm{pH}$, bacterial vaginosis and aerobic vaginitis: prevalence in early pregnancy and risk of spontaneous preterm delivery, a prospective study in a low socioeconomic and multiethnic South American population. BMC Pregnancy Childbirth. 2014 Mar 19; 14: 107. doi: 10.1186/1471-2393-14-107.
[6] St John E, Mares D, Spear GT. Bacterial vaginosis and host immunity. Curr HIV/AIDS Rep. 2007 Feb; 4 (1): 22-8.

[7] McDonald HM, Brocklehurst P, Gordon A. Antibiotics for treating bacterial vaginosis in pregnancy. Cochrane Database Syst Rev. 2007 Jan 24; (1): CD000262. Review. Update in: Cochrane Database Syst Rev. 2013; 1: CD000262.

[8] Guise J-M, Mahon SM, Aickin M, Helfand M, Peipert JF, Westhoff C. Screening for bacterial vaginosis in pregnancy. Am J Prev Med. 2001; 20 (3): 62-72.

[9] Srinivasan S, Hoffman NG, Morgan MT, Matsen FA, Fiedler TL, Hall RW, Ross FJ, McCoy CO, Bumgarner R, Marrazzo JM, Fredricks DN. Bacterial communities in women with bacterial vaginosis: high resolution phylogenetic analyses reveal relationships of microbiota to clinical criteria. PLoS One. 2012; 7 (6): e37818.

[10] Brocklehurst P, Gordon A, Heatley E, Milan SJ. Antibiotics for treating bacterial vaginosis in pregnancy. Cochrane Database Syst Rev. 2013 Jan 31; (1): CD000262. doi: 10.1002/14651858.CD000262.

[11] Bradshaw CS, Vodstrcil LA, Hocking JS, Law M, Pirotta M, Garland SM, De Guingand D, Morton AN, Fairley CK. Recurrence of bacterial vaginosis is significantly associated with posttreatment sexual activities and hormonal contraceptive use. Clin Infect Dis. 2013 Mar; 56 (6): 777-86.

[12] Alhaj AM, Radi EA, Adam I. Epidemiology of preterm birth in Omdurman Maternity hospital, Sudan. J Matern Fetal Neonatal Med. 2010 Feb; 23 (2): 131-4.

[13] Verstraelen H, Swidsinski A. The biofilm in bacterial vaginosis: implications for epidemiology, diagnosis and treatment. Curr Opin Infect Dis. 2013 Feb; 26 (1): 86-9. doi: 10.1097/QCO.0b013e32835c20cd. Review.

[14] Redelinghuys MJ, Ehlers MM, Dreyer AW, Kock MM. Normal flora and bacterial vaginosis in pregnancy: an overview. Crit Rev Microbiol. 2016 May; 42 (3): 352-63. 